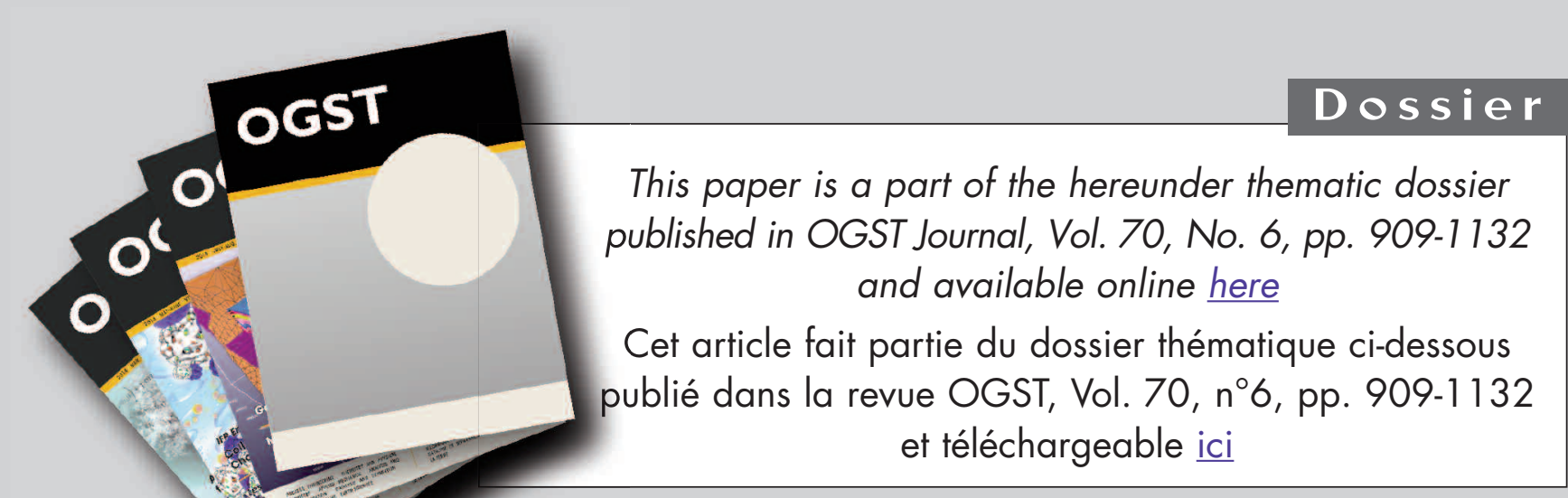

Oil \& Gas Science and Technology - Rev. IFP Energies nouvelles, Vol. 70 (2015), No. 6, pp. 909-1132

Copyright (C) 2015, IFP Energies nouvelles

909 > Editorial - Enhanced Oil Recovery (EOR), Asphaltenes and Hydrates Éditorial - EOR «récupération assistée du pétrole», Asphaltènes et Hydrates D. Langevin and F. Baudin

\section{ENHANCED OIL RECOVERY (EOR)}

917 > HP-HT Drilling Mud Based on Environmently-Friendly Fluorinated Chemicals Boues de forage HP/HT à base de composés fluorés respectueux de I'environnement

I. Henaut, D. Pasquier, S. Rovinetti and B. Espagne

931 > Effective Viscosity in Porous Media and Applicable Limitations for Polymer Flooding of an Associative Polymer

Viscosité effective dans des médias poreux et limites d'application de l'injection de polymères associatifs

P. Zhang, Y. Wang, Y. Yang, W. Chen and S. Bai

$941>$ Dynamic Gelation of HPAM/Cr(III) under Shear in an Agitator and Porous Media Gélification dynamique de HPAM/Cr(III) sous cisaillement dans un agitateur et en milieu poreux

Y. Haiyang, W. Yefei, Z. Jian, L. Peng and S. Shenglong

$951>$ Computer Modeling of the Displacement Behavior of Carbon Dioxide in Undersaturated Oil Reservoirs

Modélisation par ordinateur du comportement de déplacement du dioxyde de carbone dans des réservoirs d'huile non saturés

B. Ju, Y.S. Wu and J. Qin

$967>$ Predicting CO, Minimum Miscibility Pressure (MMP) Using Alternating Conditional Expectation (ACE) Algorithm

Prédiction de la pression miscibilité minimum (MMP) du CO en utilisant un algorithme basé sur l'ACE (Alternating Conditional Expectation)

0 . Alomair, A. Malallah, A. Elsharkawy and M. Iqbal

983 > Towards the Development of Bitumen Carbonates: An Integrated Analysis of Grosmont Steam Pilots

Vers le développement des carbonates bitumineux : une analyse intégrée des pilotes vapeur de Grosmont

C.C. Ezeuko, J. Wang, M.S. Kallos and I.D. Gates

1007> A Novel Model of Foam Flooding Considering Multi-Factors for Enhancing Oil Recovery

Un nouveau modèle d'injection de mousse considérant de multiples facteurs afin d'améliorer la récupération de pétrole

J. Wang, H. Liu, H. Zhang, G. Zhang, P. Liu and K. Sepehrnoori
1025> Testing of Snorre Field Foam Assisted Water Alternating Gas (FAWAG) Performance in New Foam Screening Model

Vérification des performances de la méthode FAWAG (Foam Assisted Water Alternating Gas) sur le champ de Snorre, en Norvège, avec un nouveau modèle de sélection des mousses

P. Spirov and S. Rudyk

\section{ASPHALTENES}

1035> Structural Study of Asphaltenes from Iranian Heavy Crude Oil Étude structurale d'asphaltènes de pétrole brut lourd iranien L. Davarpanah, F. Vahabzadeh and A. Dermanaki

$1051>$ Experimental Study and Mathematical Modeling of Asphaltene Deposition Mechanism in Core Samples

Étude expérimentale et modélisation mathématique du mécanisme de déposition d'asphaltène dans des carottes de forage

T. Jafari Behbahani, C. Ghotbi, V. Taghikhani and A. Shahrabadi

1075> Prediction of the Gas Injection Effect on the Asphaltene Phase Envelope Prévision Prévision de l'effet d'injection de gaz sur l'enveloppe de phase des asphaltènes P. Bahrami, R. Kharrat, S. Mahdavi and H. Firoozinia

\section{HYDRATES}

1087> Methane Hydrate Formation and Dissociation in the Presence of Silica Sand and Bentonite Clay

Formation et dissociation d'hydrates de méthane en présence de sable de silice et d'argile de bentonite

V. Kumar Saw, G. Udayabhanu, A. Mandal and S. Laik

$1101>$ Prediction of Mass Flow Rate in Supersonic Natural Gas Processing Prédiction du débit massique dans les applications de traitement supersonique du gaz naturel

C. Wen, X. Cao, Y. Yang and Y. Feng

$1111>$ Experimental Study on Hydrate Induction Time of Gas-Saturated Water-in-Oil Emulsion using a High-Pressure Flow Loop

Étude expérimentale sur le temps d'induction d'hydrate d'une émulsion eau-enhuile saturée en gaz en utilisant une boucle à circulation sous haute pression X.F. Lv, B.H. Shi, Y. Wang, Y.X. Tang, L.Y. Wang and J. Gong

1125> Hollow Silica: A Novel Material for Methane Storage La silice creuse : un nouveau matériau pour le stockage de méthane V.D. Chari, P.S.R. Prasad and S.R. Murthy 


\title{
Testing of Snorre Field Foam Assisted Water Alternating Gas (FAWAG) Performance in New Foam Screening Model
}

\author{
Pavel Spirov* and Svetlana Rudyk \\ Sultan Qaboos University - Department of Petroleum and Chemical Engineering, PO Box 34, Al-Khod 123, Muscat - Sultanate of Oman \\ e-mail: pavlicica3@gmail.com - svetrud77@mail.ru \\ * Corresponding author
}

\begin{abstract}
Eclipse Functional Foam Model was used in order to provide a guideline for the history matching process (Gas-Oil Ratio (GOR), oil and gas production rates) to the Foam Assisted Water Alternating Gas method in the Snorre field, Norway, where the surfactant solution was injected in two slugs to control gas mobility and prevent gas breakthrough. The simulation showed that the first short slug was not efficient while significant GOR decrease and incremental oil production was obtained after the second longer slug in some periods. This study shows that the Eclipse foam model is applicable to the planning of water and gas injections, the testing of various surfactant properties, and the evaluation of the efficiency of the method at the field scale.
\end{abstract}

Résumé - Vérification des performances de la méthode FAWAG (Foam Assisted Water Alternating Gas) sur le champ de Snorre, en Norvège, avec un nouveau modèle de sélection des mousses - Le modèle Éclipse "Functional Foam" a été utilisé pour guider le processus de calage des données de production (rapport gaz-huile, débits d'huile et de gaz) du champ Snorre, en Norvège, dans le cas d'une exploitation par une méthode d'injection alternée d'eau et de gaz avec mousse. La solution d'agents tensioactifs a été injectée en deux bouchons afin de contrôler la mobilité du gaz et d'empêcher la percée de gaz. La simulation a permis d'observer que le premier bouchon n'était pas suffisamment efficace, alors qu'une diminution significative du rapport gaz/huile et qu'une augmentation importante de la production en huile étaient constatées après le second bouchon pour certaines périodes. Cette étude démontre que le modèle Éclipse dédié aux mousses, permet de planifier les injections d'eau et de gaz, de tester les différentes propriétés des tensioactifs et d'évaluer l'efficacité de la méthode à l'échelle d'un champ pétrolier. 


\section{SYMBOLS AND NOTATIONS}

$\begin{array}{ll}t & \text { Time } \\ V & \text { Block pore volume } \\ S_{w} & \text { Water saturation } \\ C_{f} & \text { Foam concentration } \\ B_{r}, B_{w} & \text { Rock and water formation volume } \\ \rho_{r} & \text { Rock density } \\ C_{f}^{a} & \text { Foam concentration adsorbed on to the rock } \\ \phi & \text { Porosity } \\ \Sigma & \text { Sum over neighbouring cells } \\ T & \text { Transmissibility } \\ k_{r w} & \text { Water relative permeability } \\ \mu_{w} & \text { Water viscosity } \\ M_{r f} & \text { Foam mobility reduction factor } \\ P_{w} & \text { Water pressure } \\ \rho_{w} & \text { Water density } \\ D_{z} & \text { Cell centre depth } \\ Q_{w} & \text { Water production rate } \\ \lambda & \text { Rate decay parameter function of oil and water }\end{array}$

$\lambda \quad$ Rate decay parameter function of oil and water saturation

$S_{o} \quad$ Oil saturation

$M_{r} \quad$ Reference mobility reduction factor

$F_{s} \quad$ Mobility reduction function due to surfactant concentration

$F_{w} \quad$ Mobility reduction function due to water saturation

$F_{o} \quad$ Mobility reduction function due to oil saturation

$F_{c} \quad$ Mobility reduction function due to capillary number

$C_{s} \quad$ Surfactant concentration

$C_{s}^{r} \quad$ Reference surfactant concentration

$e_{s} \quad$ Steepness of the transition

$S_{o}^{m} \quad$ Maximum oil saturation above which the foam ceases to be effective

$e_{o} \quad$ Exponent which controls the steepness of the transition about the point where $\mathrm{S}_{o}=S_{o}^{m}$

$S_{w}^{1} \quad$ Limiting water saturation below which the foam cease to be effective

$f_{w} \quad$ Weighing factor which controls the sharpness in the changes in mobility

$N_{c} \quad$ Capillary number

$N_{c}^{r} \quad$ Reference capillary number

$e_{c} \quad$ Exponent which controls the steepness of the transition about the point where $N_{c}=N_{c}^{r}$

GIR Gas Injection Rate (simulated)

GIRH Gas Injection Rate Historical

GPR Gas Production Rate (simulated)

GPRH Gas Production Rate Historical
GOR Gas Oil Ratio (simulated)

GORH Gas Oil Ratio Historical

OPR Oil Production Rate (simulated)

OPRH Oil Production Rate Historical

\section{INTRODUCTION}

\section{Foam Behaviour}

The usual problem of gas injection methods is early gas breakthrough. Foam applications can solve the problems of gas mobility control and store more gas in reservoirs by building a bank behind the oil, delaying early gas breakthroughs and reducing the gas oil ratio (Skauge et al., 2002). Foam is generated when gas, passing through surfactant in an aqueous phase, creates a stable dispersion of gas bubbles and lamellae trains in the liquid. With an objective of reducing the gas-oil ratio in production wells, it is essential to have foam that is immobile after placement. Stationary or trapped foam can block a large number of channels that would otherwise carry gas. When foam bubbles form in a porous medium, the bubble size typically matches the pore size of the rock. These bubbles tend not to move until they are compressed (hence, reducing their size) through the application of a higher pressure, which in turn leads to more bubbles being generated ('The Foam Model', 2012). The effect of the size of the bubbles, the longevity of the foam and the impact of the oil and water on the foam's strength and stability have been described in numerous studies. It has been observed by (Hirasaki and Lawson, 1985) that bubbles of smaller sizes are less mobile than larger bubbles. A low permeable matrix has a detrimental effect on the foam strength because of stretching and squeezing, whereas foam flowing through pores and throats causes thin films to break, foam coalescence occurs and bubble size increases, which leads to an increase in foam mobility (Ashoori et al., 2010). Typically, the reduction of gas mobility depends on a range of factors, including pressure and shear rate (Prud'homme and Khan, 1996).

The physics of the foam flooding process is very complex. Low foam density causes the fractionation of the flow, while low foam viscosity leads to fingering and channelling. Foam will collapse if the water saturation is below, or the oil saturation is above, certain values. Foam also disappears through natural decay and due to the adsorption by the rock surface, which implies that the foam properties vary with space and time. At higher temperatures and more acidic media the rate of decay increases (Angstadt and Tsao, 1987). In foam flooding, 
the foam properties have a decisive impact on the efficiency of the method while the reduction of the interfacial tension (between oil and water) has no significant effect.

To apply foam for Enhanced Oil Recovery (EOR) one must understand both the physical interactions between foam and oil in porous media and how these interactions are represented in computer models (Farajzadeh et al., 2012). Recent studies have shown that foam rheology in porous media can be characterised by foam catastrophe theory, which exhibits three foam states (weakfoam, strong-foam and intermediate states) and two strong foam regimes (high-quality and low-quality) (Afsharpoor et al., 2010).

In computer models, foam is classified as strong foam (immobile foam) and weak foam (flowing foam). The model simulates the reduction of gas mobility in the presence of the foam, which is accomplished by reducing the relative permeability of the gas, increasing its viscosity, or a combination of both. The foam generation, foam movement and its effect on gas mobility are taken into consideration. The surfactant is distributed in terms of concentration in the cells. The surfactant concentration is divided into adsorbed foam, decayed foam and remaining foam, or an effective concentration that will act to change the mobility. The interaction of the foam with all available media in the reservoir, such as water, oil and rock, is formulated mathematically in order to model the project performance. The shape of the fractional flow curve changes with injection velocity; a weak foam state is obtained at low injection velocity and a strong foam state is achieved at high injection velocity (Dholkawala et al., 2007). The foam can be transported by either water or gas; the two options for a tracer. Gas tracer studies measure the fraction of gas trapped within the foam at steady state (Kovscek, 1998).

Considering the beneficial effects of foam for mobility control for gas, numerous laboratory studies have been conducted (Zuta and Fjelde, 2011) but few field-scale pilot projects are available for the application of the theories and methodologies defined in the literature for foam (Shabib-Asl et al., 2013).

\section{FAWAG at Snorre Field}

The Foam Assisted Water Alternating Gas (FAWAG) technique implemented in the Snorre field, Norway, has become the world's largest application of four pilot projects in different parts of the field. The pilots covered gas shut off in production wells, mobility control and the diversion of injected gas.
Most of the North Sea reservoirs are composed of massive sandstone fluvial deposits within rotated fault blocks. The properties of this reservoir type are high temperature of $90^{\circ} \mathrm{C}$ and high pressure of more than 383 bar at $2475 \mathrm{~m}$ in Statfjord and Lunde formations. Permeability is changing in streaks in the range of 100-3 $000 \mathrm{mD}$ (Skauge et al., 2002). The injected gas contained $70 \%$ of methane.

Rapid development of gas production after gas breakthrough might cause a severe problem for some North Sea oil fields. In these fields, the gas front will reach all the production wells almost simultaneously. Gas handling might put restrictions on further oil production and thus, any means by which to delay gas breakthrough is desirable. Side tracking of the production wells to lower parts of the formation intervals might be beneficial. Zone-isolation or blocking of the higher perforations appears difficult by traditional well treatments. For those reasons, the use of foam to block a gas cone and delay the GOR development of the wells has received much attention (Aarra et al., 2002).

The project originally started in 1997 in the Central Fault Block (CFB) of the Snorre field. Owing to problems associated with the fracturing and gas leakages, the injection area was changed to the Western fault block of the Snorre field. The experience from the tests in the CFB had identified that surfactant alternating gas was the best injection method. Well P-32 was chosen as an injector to reduce the producing GOR at production well $\mathrm{P}-39$, which is located at a distance of $1550 \mathrm{~m}$.

Gas, water and surfactant were injected periodically into the injector following schedule shown in Figure 1. An initial short cycle of foam injection observed in laboratory experiments (Aarra et al., 2002) was more efficient than later injections. In addition, owing to the establishment of trapped gas saturation in the area after the first gas injection and mass exchange reduction

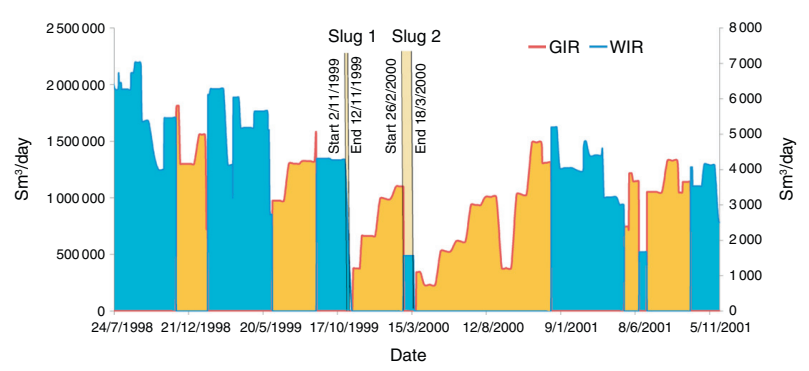

Figure 1

Schedule and injection rates: gas injection rate for well P-32G and water injection rate for well P-32W. Surfactant injections are shown in slugs. 
between the oil and gas in the second gas injection period, gas breakthrough is expected to arrive earlier. Therefore, the surfactant injection of $\mathrm{C}_{14-16}$ commercial grade alpha olefin sulfonate or AOS-16 3-hydroxy sulfonate was applied in two slugs: an initial short foam cycle of the brine surfactant slug injection was in period from $2 / 11 / 1999$ to $12 / 11 / 1999$, which was followed by the gas injection from $12 / 11 / 1999$ to $26 / 2 / 2000$. The surfactant concentration used for the simulator was $4.9 \mathrm{~kg} / \mathrm{Sm}^{3}$ and the cumulative surfactant injection over nine days was $15262 \mathrm{Sm}^{3}$. The second foam cycle was begun by an injection of a brine surfactant slug from $26 / 2 / 2000$ to $17 / 3 / 2000$ followed by gas injection from $17 / 3 / 2000$ to $20 / 12 / 2000$. The injection for the Water Alternating Gas (WAG) cycle started immediately after the end of FAWAG cycle, which was on 20/12/2000. The surfactant concentration for second slug was $2 \mathrm{~kg} / \mathrm{Sm}^{3}$ and the cumulative injection equal to $31733 \mathrm{Sm}^{3}$. During the injection of the surfactant solution and gas, the injection rate was adjusted to ensure that the fracturing pressure was not exceeded.

The objectives of the field trial of the Snorre projects were as follows: to reduce the producing GOR in production well P-39 and to increase the sweep efficiency during gas injection and the storage of gas in the reservoir. The numerical simulation of the performance at the Snorre field using the Eclipse Foam Model is described in this study.

\section{ECLIPSE FOAM PROPERTIES MODELING}

In ECLIPSE 2009.1, the foam model has been extended to provide water as a transport phase in addition to gas. Accompanying this, a new functional model for the gas mobility reduction factor $\left(M_{r f}\right)$ has been implemented. The foam carrier (tracer) for the functional model is bubbles generated in the water and the gas velocity is not considered.

Therefore, the foam distribution between all members of the equation $C_{f}$ is described by Equation (1) as a function of water properties:

$$
\begin{aligned}
& \frac{d}{d t}\left(\frac{V S_{w} C_{f}}{B_{r} B_{w}}\right)+\frac{d}{d t}\left(V \rho_{r} C_{f}^{a} \frac{1-\phi}{\phi}\right) \\
& \quad=\sum\left[\frac{T k_{r w}}{B_{w} \mu_{w}}\left(\delta P_{w}-\rho_{w} g D_{z}\right)\right] C_{f} \\
& \quad+Q_{w} C_{f}-\lambda\left(S_{w}, S_{o}\right) V C_{f}
\end{aligned}
$$

The basic equation for the modeling is derived from the combination of Darcy's Law and the Buckley-Leverett equation. The volume of the generated foam, when surfactant is added into water, depends on the volume of water and is calculated as:

$$
\left(\frac{V S_{w} C_{f}}{B_{r} B_{w}}\right)
$$

The part of the surfactant adsorbed by the rock is represented by:

$$
V\left(\frac{1-\emptyset}{\emptyset}\right) \cdot \rho_{r} \cdot C_{f}^{\alpha}
$$

During time increment $d t$, the foam passing through a volume element of rock is calculated as:

$$
\left[\frac{T k_{r w}}{B_{r} \mu_{w}}\left(\sigma P_{w}-\rho_{w} g D_{Z}\right)\right] C_{f}
$$

The foam travelling in the water phase is $Q_{W} C_{f}$.

The foam decay due to oil and water over time is modeled by the foam decay $\lambda\left(S_{w}, S_{o}\right) V C_{f}$.

The foam mobility reduction factor $\left(M_{r f}\right)$ is a numerical multiplier taken from the functional model of Eclipse:

$$
M_{r f}=\frac{1}{1+\left(M_{r} \cdot F_{s} \cdot F_{w} \cdot F_{o} \cdot F_{c}\right)}
$$

For this model, the gas mobility reduction factor is modeled in terms of a set of functions that represents the individual reduction factors due to the surfactant concentration $\left(F_{s}\right)$, oil saturation $\left(F_{o}\right)$, water saturation $\left(F_{w}\right)$ and capillary number $\left(F_{c}\right)$. These are combined multiplicatively with a reference mobility reduction factor $\left(M_{r}\right)$ to determine the net mobility reduction factor $\left(M_{r f}\right)$ as shown in Figure 2.

Each of the foam controlling functions, such as $F_{s}, F_{o}$, $F_{w}$, and $F_{c}$ is dependent on how surfactant behaves when it interacts with the porous media and regulated by two parameters: the property itself, which needs to be found by laboratory tests, and its exponent/weighting factor.

The reference mobility reduction factor $M_{\mathrm{r}}$ is typically in the range of 5 to 100 and corresponds to the normalised resistance to flow for a minimum bubble size in the absence of factors that increase bubble size. The values of $\left(M_{r f}\right)$ can vary between 0 and 1 , where " 0 " means no gas flow.

Variations of the five functions can produce a large number of combinations, and the effect of one property can be compensated by effect of the other property. The most important function is $F_{s}$, while the other functions tend to change it, which after multiplying with $M_{r}$ results in the reduction of gas flow. 


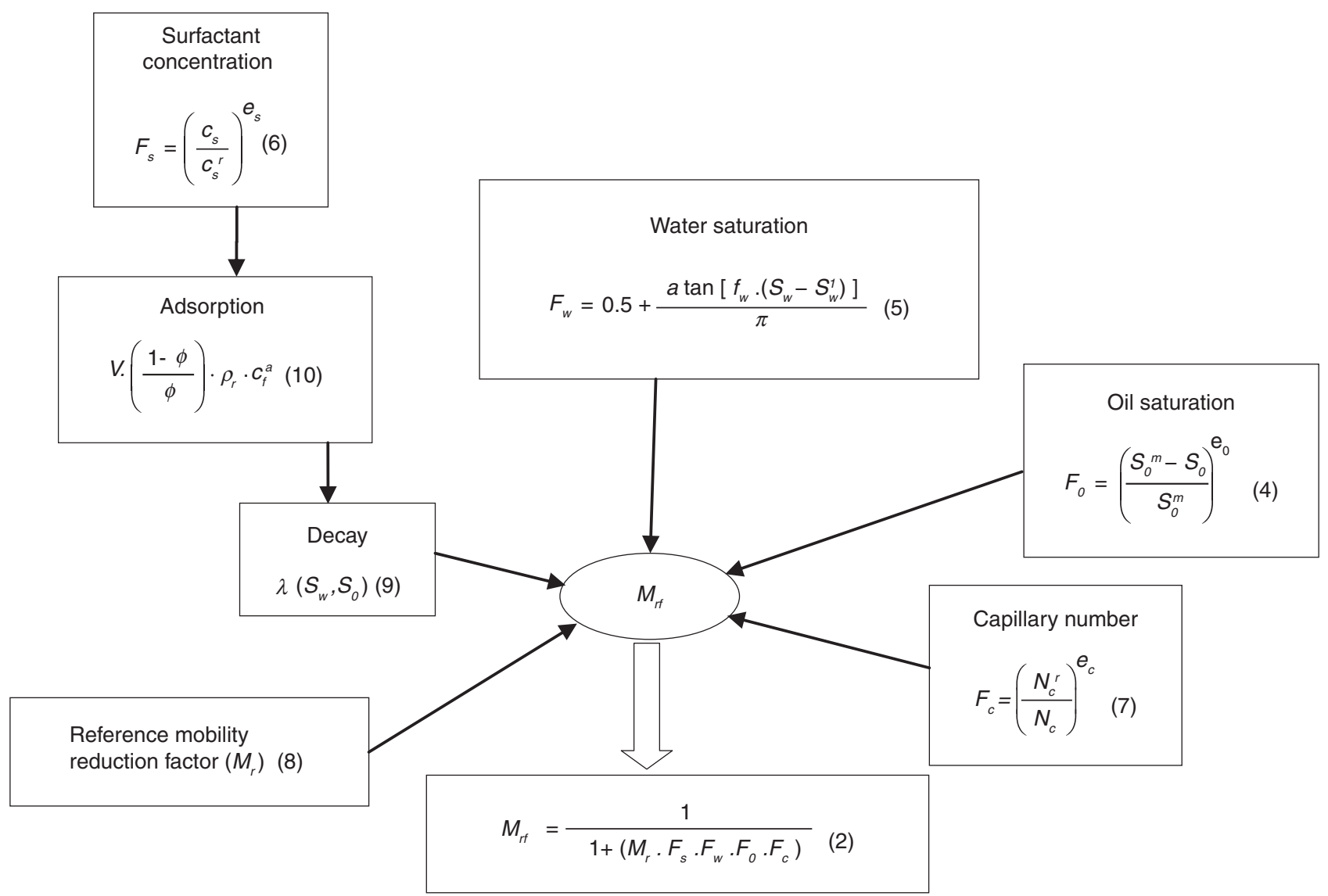

Figure 2

Concept of the foam model.

To study the contribution of each of the functions to a general performance, their alterations were initially studied as a sensitivity analysis. The details of the sensitivity of each property were described in SPE_150829 (Spirov et al., 2012). The individual effect of each of the functions on foam mobility is estimated on the assumption that the other functions are equal to 1 . For example, in Equation (3) foam mobility is calculated as a function of surfactant concentration $F_{s}$. To calculate the $M_{r f}$ as a function of either capillary number $\left(F_{c}\right)$ or oil saturation $\left(F_{o}\right)$, or water saturation $\left(F_{w}\right),\left(F_{s}\right)$ should be replaced with either function in this equation:

$$
M_{r f}=\frac{1}{1+\left(M_{r} \cdot F_{s}\right)}
$$

The simulations were performed for the purpose of the sensitivity analysis to determine the variations of the property values affecting the shape and magnitude of the GOR curve with respect to historical GORH. Based on the results of the sensitivity analysis, the values providing the best match between the historical and simulated data were selected and shown in Table 1 .

\section{RESULTS AND DISCUSSION}

\subsection{Modeling of the Well Performance}

In this section, we highlight a few of the simulated production responses at the producer P-39, together with a look back on historical trends compared against simulations of scenarios with and without foam.

To find the best match for the Snorre foam cycles, various combinations of variables, such as: the mobility reduction factor $M_{r}$, capillary number exponent, surfactant concentration exponent, oil $\left(S_{o}\right)$, and water $\left(S_{w}\right)$ saturations were tried at the given constant critical 
TABLE 1

Best match of values of foam parameters used for simulation in Eclipse

\begin{tabular}{|c|c|c|c|}
\hline Functions & Equation & Variable & Exponent \\
\hline Oil saturation function $\left(F_{o}\right)$ & (4) & $S_{o}^{m}=0.1$ (best match 0.4$)$ & $e_{o}=1$ \\
\hline Surfactant conc. function $\left(F_{S}\right)$ & (6) & $C_{s}^{r}=0.1 \mathrm{~kg} / \mathrm{Sm}^{3}$ & $e_{s}=1$ \\
\hline Capillary number function $\left(F_{c}\right)$ & (7) & $N_{c}^{r}=1.0 \mathrm{e}-7$ & $e_{c}=0.1$ \\
\hline \multirow{2}{*}{$\begin{array}{l}\text { Foam reference mobility reduction } \\
\text { factor for foam in water phase }\left(M_{r}\right)\end{array}$} & (8) & $M_{r}=50$ & l \\
\hline & & & Weighing factor \\
\hline \multirow[t]{2}{*}{ Water saturation function $\left(F_{w}\right)$} & (5) & $S_{w}^{1}=0.1$ & $f_{w}=10$ \\
\hline & & Foam surfactant concentration & $\begin{array}{c}\text { Corresponding gas-water surface } \\
\text { tension }\end{array}$ \\
\hline \multirow[t]{2}{*}{$\begin{array}{l}\text { Gas-water interfacial tension as a } \\
\text { function of foam surfactant } \\
\text { concentration }\end{array}$} & / & $\begin{array}{c}0 \mathrm{~kg} / \mathrm{Sm}^{3} \\
0.01 \mathrm{~kg} / \mathrm{Sm}^{3} \\
0.05 \mathrm{~kg} / \mathrm{Sm}^{3}\end{array}$ & $\begin{array}{l}10 \mathrm{mN} / \mathrm{m} \\
5 \mathrm{mN} / \mathrm{m} \\
0.1 \mathrm{mN} / \mathrm{m}\end{array}$ \\
\hline & & Local oil or water saturation & Corresponding decay half-life \\
\hline \multirow[t]{2}{*}{$\begin{array}{l}\text { Foam oil decay function foam water } \\
\text { decay function }\end{array}$} & (9) & $\begin{array}{c}0 \\
1 \\
\text { Not used }\end{array}$ & $\begin{array}{l}3000 / \text { day } \\
2500 / \text { day } \\
\text { Not used }\end{array}$ \\
\hline & & $\begin{array}{l}\text { Local foam concentration in the } \\
\text { solution surrounding the rock }\end{array}$ & $\begin{array}{l}\text { Saturated concentration of foam } \\
\text { adsorbed by the rock formation }\end{array}$ \\
\hline Foam adsorption & (10) & $\begin{array}{c}0 \\
1 \\
30\end{array}$ & $\begin{array}{c}0 \mathrm{~kg} / \mathrm{rm}^{3} \\
1.0 \mathrm{e}-5 \mathrm{~kg} / \mathrm{rm}^{3} \\
1.0 \mathrm{e}-5 \mathrm{~kg} / \mathrm{rm}^{3}\end{array}$ \\
\hline
\end{tabular}

surfactant concentration of 0.1 and limiting capillary number of 1.0e-7. The values of $M_{r}=50, F_{o}=(0.4,1)$, $F_{w}=(0.1,10), F_{s}=(0.1,1)$ and $F_{c}=(1.0 \mathrm{e}-7,0.1)$ provided the best match.

History Gas-Oil Ratio (GORH) and the best match for foam GOR are plotted together in Figure 3. Five periods of elevated GORH values, called peaks and denoted as: 1, 2, 3, 4 and 5, are distinguishable from the beginning of the gas injection until the end of 2001. The surfactant injection periods are shown as slug 1 and slug 2 starting at the end of the $2^{\text {nd }}$ peak. The present simulations aimed to obtain the best match of GORH and GOR of the peaks numbered 3,4 and 5 .

The $3^{\text {rd }}$ peak of GOR was predicted two-and-a-half months later than GORH. GOR in the interval between the $3^{\text {rd }}$ and $4^{\text {th }}$ peaks matched in time but was lower in value. The $4^{\text {th }}$ peak matched satisfactorily. GOR in the interval between the $4^{\text {th }}$ and $5^{\text {th }}$ peaks was higher than GORH; the start of the $5^{\text {th }}$ peak was predicted 3 months earlier. Because GORH is a result of the division of oil $(\mathrm{OPRH})$ and gas $(\mathrm{GPRH})$ production rates, the match

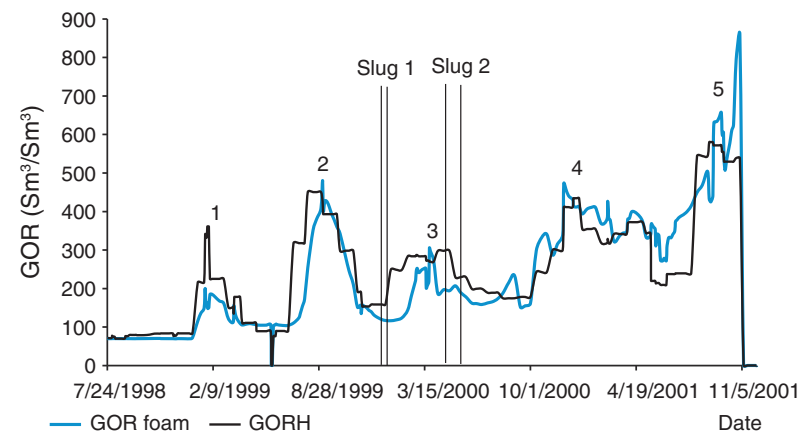

Figure 3

Best match of foam simulated GOR compared to GORH.

of the aforementioned parameters and their simulation were analysed.

The foam model predicted higher oil production OPR due to the surfactant injection immediately after $1^{\text {st }}$ slug, as can be seen in Figure 4. Simulated OPR closely 


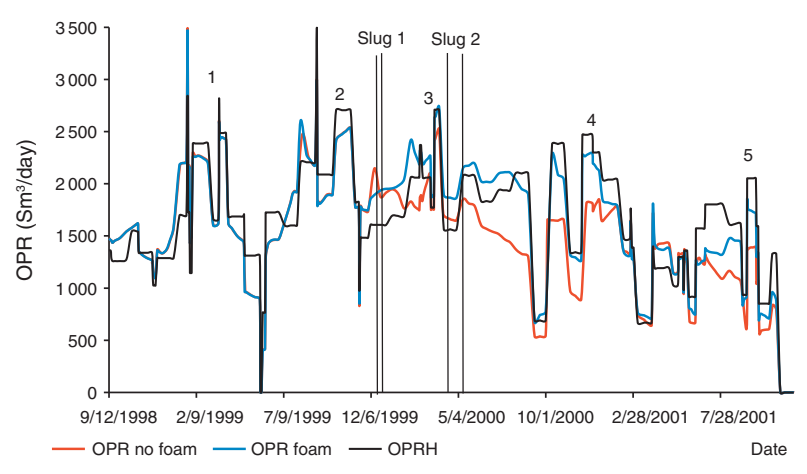

Figure 4

Best match of foam simulated OPR and no foam scenario compared to OPRH.

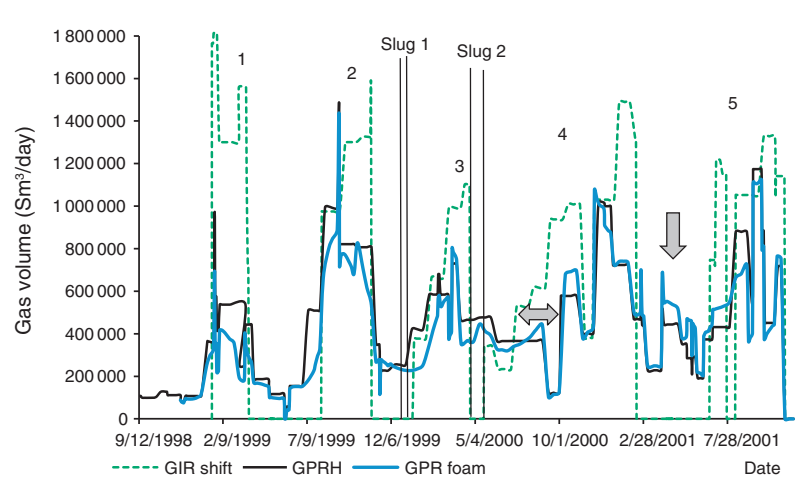

Figure 5

Comparison of gas injection GIR (plotted with 56 days of shift) and gas production GPRH. Arrows point out the delay of GPRH compared to GIR and small peak between 4 th and 5 th peaks occurred due to foam effect. matched to OPRH after the $2^{\text {nd }}$ slug in the periods of $3^{\text {rd }}$ and $4^{\text {th }}$ peaks while the oil production OPRH was much higher than the simulated OPR at the beginning of the $5^{\text {th }}$ peak during about two months.

In order to analyse the response of the injection in the production well, the Gas Injection Rate (GIR) was shifted at 56 days to find the match with the GPRH and plotted additionally in Figure 5. The shift shows a period of gas travelling from the injector to the producer. To find a match with the $5^{\text {th }}$ GORH peak, the GIR was shifted at 40 days indicating that the duration of the gas travel became shorter by the end of the project. Totally, $1.32 \times 10^{8} \mathrm{Sm}^{3} /$ day was injected, whereas $1.3 \times 10^{8} \mathrm{Sm}^{3} /$ day was produced.

The $3^{\text {rd }}$ peak at GPR started with approximately two months delay predicting an immediate foam generation. The divergence between GPRH and GPR between the $3^{\text {rd }}$ and the $4^{\text {th }}$ peaks is not substantial. All the other peaks of GPR mimic the shape of the GPRH with a few exceptions. The general observation of Figure 4 and Figure 5 allows making conclusion that in the periods, where the foam model overestimates GPR, the OPR is underestimated and vice versa, causing the divergence between GOR and GORH in the corresponding periods. For example, the beginning of the $5^{\text {th }}$ peak in GOR starts two months later than at OPR/OPRH and GPR/GPRH due to the underestimation of oil production and overestimation of gas production. It can be also deduced that the GPR values are simulated more accurately than OPR, and due to that the GOR values are more affected by oil production rate. The higher oil production rates at the start of the $5^{\text {th }}$ peak, long after the completion of the last surfactant injection, could probably be attributed to the delayed foam effect. In addition, first three periods of GPRH coincide in time with the gas injection (GIR), while the $4^{\text {th }}$ peak starts with the delay of 2.5 months, shown by the left-right arrow in Figure 5, reflecting the foam effect.

Additionally, the no-foam scenario was modeled to view how the production would have occurred if surfactants were not applied. For the no-foam model, the start of the $3^{\text {rd }}$ period was delayed at one month and the simulated GOR was much higher (Fig. 6).

There was no delay between the $3^{\text {rd }}$ peaks of GIR and GORH, indicating that the foam was not strong enough after the initial small slug, as could have been expected from laboratory investigations (Schramm, 1994). The no-foam model suggests that if the foam was not applied, the entire $4^{\text {th }}$ period would have occurred five to six months earlier than it actually did and at much higher GOR values (Fig. 6). The model also predicted that GOR in the $5^{\text {th }}$ period could have been much higher and gas would have arrived two to three months earlier.

The GPR of no-foam scenario very closely followed GPRH in the period of the $3^{\text {rd }}$ peak in Figure 7, indicating that the surfactant injection did not influence gas flow after the $1^{\text {st }}$ slug. The 56 days of travel time between injector and producer similar to the $1^{\text {st }}$ and $2^{\text {nd }}$ periods, when no surfactant was injected, confirmed that. It needs to be noted that no injections have occurred during 6 days after the $1^{\text {st }}$ slug. Probably due to that the foam generation delayed, whereas the model predicted immediate foam effect. To match the history data, the simulation of the $3^{\text {rd }}$ peak should be done using $M_{r}=1$. The $3^{\text {rd }}$ peak of GOR for the no-foam model transformed 


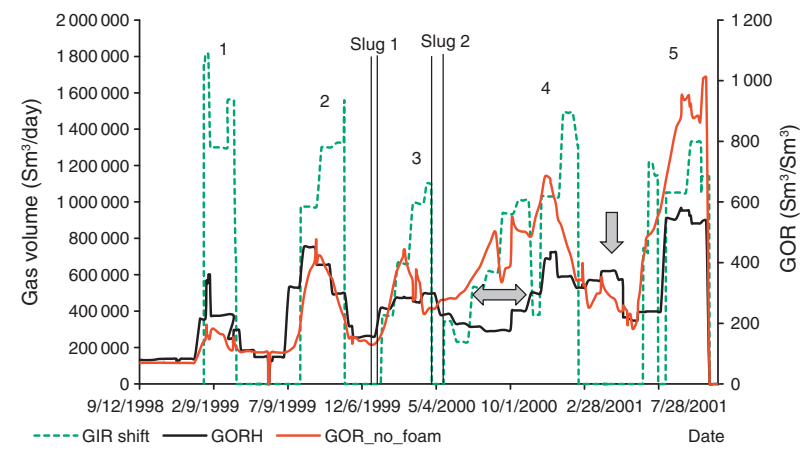

Figure 6

Comparison of GIR shifted at 56 days with GOR and GORH.

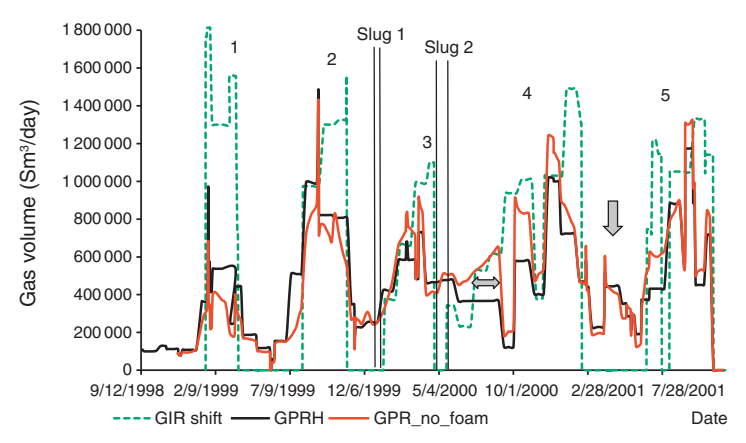

Figure 7

Comparison of gas injection GIR (plotted with 56 days of shift) and gas production GPRH. Arrows point out the delay of GPRH compared to GIR and small peak between 4th and 5th peaks occurred due to foam effect.

smoothly into the $4^{\text {th }}$; however, there is a clear boundary between the $3^{\text {rd }}$ and $4^{\text {th }}$ peak of GPR. Similarly to GIRGPRH, the beginning of the $4^{\text {th }}$ peak at GIR occurred approximately three-and-a-half months earlier than the $4^{\text {th }}$ peak at GOR. The $2^{\text {nd }}$ horn of the $4^{\text {th }}$ peak of GORH, shown as the down arrow, occurred when there was no gas injection and GPRH was not high.

It could be deduced that although the view of GOR depending on both GPR and OPR distorted the real vision of the peaks distribution, the gas breakthrough at the beginning of the $4^{\text {th }}$ period, shown by the left-right arrow, was significantly reduced after the $2^{\text {nd }}$ slug but not postponed.

\subsection{Comparison with the Previous Simulations Studies}

Few studies have been devoted to foam simulation on a field scale.
Previous simulation of the foam performance for WFB of the Snorre field was performed using the STARS model. The model implemented in Eclipse by Statoil was converted to STARS and a sector of WFB was selected for a rapid sensitivity analysis in SPE 75157 (Skauge et al., 2002) and SPE 77695 (Aarra et al., 2002). It was believed that the STARS model is the best option to simulate foam under Snorre field conditions, but comparable simulators containing the essential foam parameter are LE foam model, UTCHEM, Shell simulator MoReS. The field-observed GORH behaviour following the second surfactant injection, performed in the period 26/2-15/3/2000, indicated a constant GORH for several months. The general trend in all the simulation runs showed an increasing GOR with time. This behaviour was very difficult to match using foam simulations. The lack of history match of the field-observed GORH development, after the second surfactant slug, made it difficult to describe the possible properties of the foam generated in the reservoir (Skauge et al., 2002).

This paper describes the approbation of a new foam functional screening model in ECLIPSE 2009.1 software, using foam as the tracer in the water phase and the selection of the foam parameters that could better match the model to actual data. Previous 2002 and 2006 Eclipse versions contained tabular model. Since that time, the foam conservation equation has been fully upgraded in Equation (1) and many new properties shown in Figure 1 were not present in older versions of Eclipse.

Compared with earlier simulations performed in 20022005 , the history match of the field data with simulated in the present study is extended for the entire period from 12 September 1998 - 1 January 2003 and includes the periods of the $4^{\text {th }}$ and $5^{\text {th }}$ peaks. Comparison with the simulation results from previous work in STARS (Aarra et al., 2002) can be made only for the $3^{\text {rd }}$ peak due to unavailability of the other data. STARS predicted the similar delay in GOR of approximately two months. We have shown that the delay is caused by the overestimation of the Oil Production Rate (OPR), because both simulators predict the immediate foam generation after the $1^{\text {st }}$ slug. Whether that is due to the absence of any injections following the $1^{\text {st }}$ slug is difficult to determine.

\section{CONCLUSIONS}

The simulation of the FAWAG performance using the New Eclipse Functional Foam model matches the historical data for the entire period from 12 September 1998 - 1 January 2003. The best match of GORH and GOR was obtained at $S_{o}^{m}=0.4$. 
The $1^{\text {st }}$ surfactant slug did not reduce gas production rate substantially while the effect of the $2^{\text {nd }}$ slug on the gas production rate decrease can be traced in the period of the $4^{\text {th }}$ peak and on the oil production rate increase in the period of the $5^{\text {th }}$ peak.

A comparison of runs with and without foam showed that although the presence of foam reduced the GORH and GPRH considerably, it did not stop or delay gas flow.

To improve the match of the GOR with history data, some discrepancies between over- and underestimations of GPR and OPR should be eliminated. Multiple $M_{r}$ 's should be used for different foam cycles rather than just one single value.

\section{ACKNOWLEDGMENTS}

The authors would like to thank Statoil ASA for authorizing data presented in this paper, Schlumberger Technology Centre and Arif Khan for advisory and software support.

\section{REFERENCES}

Aarra M.G., Skauge A., Martinsen H.A. (2002) FAWAG: A Breakthrough for EOR in the North Sea, SPE Annual Technical Conference and Exhibition, San Antonio, Texas, 29 Sept.-2 Oct.

Afsharpoor A., Lee G., Kam S. (2010) Mechanistic simulation of continuous gas injection period during Surfactant-Alternating-Gas (SAG) processes using foam catastrophe theory, Chemical Engineering Science 65, 11, 3615-3631.

Angstadt H., Tsao H. (1987) Kinetic Study of the Decomposition of Surfactants for EOR, SPE Reservoir Engineering 2, 4, 613-618.

Ashoori E., van der Heijden T., Rossen W. (2010) Fractionalflow theory of foam displacements with oil, SPE Journal 15, 2 , 260-273.
Dholkawala Z.F., Sarma H.K., Kam S.I. (2007) Application of fractional flow theory to foams in porous media, Journal of Petroleum Science and Engineering 57, 1, 152-165.

Farajzadeh R., Andrianov A., Krastev R., Hirasaki G., Rossen W.R. (2012) Foam-Oil Interaction in Porous Media: Implications for Foam Assisted Enhanced Oil Recovery, SPE EOR Conference at Oil and Gas West Asia, Muscat, Oman, 16-18 April.

The Foam Model (2012) ECLIPSE Reference Manual 2012.2, Schlumberger, 341-376.

Hirasaki G., Lawson J. (1985) Mechanisms of foam flow in porous media: apparent viscosity in smooth capillaries, Old SPE Journal 25, 2, 176-190.

Kovscek A.R. (1998) Reservoir Simulation of Foam Displacement Processes, 7th UNITAR International Conference on Heavy Crude and Tar Sand, Beijing, China, 27-30 Oct.

Prud'homme R.K., Khan S.A. (1996) Foams: Theory, Measurements, and Applications, New York, Marcel Dekker Inc.

Schramm L.L. (1994) Foams: Fundamentals and applications in the petroleum industry, American Chemical Society.

Shabib-Asl A.M., Ayoub A.M., Alta'ee A.F. (2013) Application of Foam during Foam Assisted Water Alternating Gas (FAWAG) Process: A Review, International Oil and Gas Symposium and Exhibition, Sabah, Malaysia, 9-11 Oct.

Skauge A., Aarra M.G., Surguchev L., Martinsen H.A., Rasmussen L. (2002) Foam-Assisted WAG: Experience from the Snorre Field, SPE/DOE Improved Oil Recovery Symposium, Tulsa, Oklahoma, 13-17 April.

Spirov P., Rudyk S., Khan A. (2012) Foam Assisted WAG, Snorre Revisit with New Foam Screening Model, SPE North Africa Technical Conference and Exhibition, Cairo, Egypt, 20-22 Feb.

Zuta J., Fjelde I. (2011) Mechanistic Modeling of $\mathrm{CO}_{2}$-Foam Processes in Fractured Chalk Rock: Effect of Foam Strength and Gravity Forces on Oil Recovery, SPE Enhanced Oil Recovery Conference, Kuala Lumpur, Malaysia, 19-21 July.

Manuscript accepted in September 2013

Published online in April 2014 